M. Leonhardt

S. Gebert

C. Wenk

\section{Vitamin E content of different animal products: Influence of animal nutrition}

\begin{abstract}
Der Vitamin E-Gehalt verschiedener tierischer Produkte: EinfluB der Tierernährung
\end{abstract}

Zusammenfassung In der vorliegenden Studie wurde der $\alpha$-Tocopherolgehalt verschiedener Fleischstücke untersucht. Hähnchenschenkel hatte den höchsten $\alpha$-Tocopherolgehalt, gefolgt von Hähnchenbrust und Schweineschulter $(p<0.05)$. Die niedrigsten Konzentrationen wurden im Musculus longissimus dorsi vom Schwein,
Received: 5 June 1996

Accepted: 19 August 1996

M. Leonhardt - S. Gebert

Prof. Dr. C. Wenk (凶)

Institut für Nutztierwissenschaften

Gruppe Ernährungsbiologie

ETH-Zentrum, LFW

Universitätsstraße 2

CH-8092 Zürich
Rind, Kalb und in der Rindsschulter nachgewiesen. Mit dem durchschnittlichen, täglichen Verzehr an magerem Fleisch $(105 \mathrm{~g})$ in der Schweiz wurden die Empfehlungen für die tägliche Vitamin E-Zufuhr zu $3 \%$ gedeckt.

Die Supplementierung des Schweine- und Legehennenfutters mit $200 \mathrm{mg} \alpha$-Tocopherolacetat $/ \mathrm{kg}$ führte zu einem signifikanten Anstieg des $\alpha$-Tocopherolgehaltes in allen untersuchten Produkten. Die $\alpha$-Tocopherolakkumulierung unterschied sich gemäß folgender Rangordnung: Eigelb $>$ Leber $>$ Fettgewebe $>$ Musculus longissimus dorsi. Die Nährstoffdichten betrugen 28.8 , $7.3,0.9$ und $1.2 \mathrm{mg} \alpha$-Tocophe$\mathrm{rol} / \mathrm{MJ}$ für Eigelb, Leber, Fettgewebe und Musculus longissimus dorsi der jeweiligen mit Vitamin $\mathrm{E}$ supplementierten Gruppe. Diese Ergebnisse zeigen, daß Fleisch, mit Ausnahme des Hähnchenschenkels, von Tieren mit supplementierten Diäten kein bedeutender Vitamin ELieferant ist. Hingegen wurde Eigelb durch fütterungsbedingte Modifikation zu einer guten Vitamin EQuelle.

Summary The $\alpha$-tocopherol content of different meat cuts was examined. Chicken thigh had the highest vitamin $\mathrm{E}$ content, followed by chicken breast and pork shoulder $(p<0.05)$. The lowest concentrations were found in longissimus dorsi muscle from pork, beef, veal and in beef shoulder. Considering the average daily lean meat consumption (105 g) in Switzerland, recommendation for daily vitamin $E$ intake was met to $3 \%$.

Supplementation of $200 \mathrm{mg}$ $\alpha$-tocopherol acetate $/ \mathrm{kg}$ feed to pigs and laying hens significantly increased the $\alpha$-tocopherol content in all examined products. The $\alpha$-tocopherol accumulation differed according to the following ranking: egg yolk > liver > adipose tissue > musculus longissimus dorsi. The $\alpha$-tocopherol:energy ratios were $28.8,7.3,0.9$ and $1.2 \mathrm{mg} / \mathrm{MJ}$ for egg yolk, liver, adipose tissue and longissimus dorsi muscle of the vitamin $\mathrm{E}$ supplemented groups, respectively. The results showed that meat, with the exception of chicken thigh, is not an important supplier of vitamin $\mathrm{E}$, not even from animals fed a vitamin $E$ enriched diet. Egg yolk became a good source of vitamin E for human nutrition by dietary modification.

Schlüsselwörter Vitamin E Fleisch - Fettgewebe - Leber Eigelb

Key words Vitamin E - meat adipose tissue - liver - egg yolk 


\section{Introduction}

The main function of vitamin $E$ ( $\alpha$-tocopherol) is to protect susceptible cellular structures, especially polyunsaturated fatty acids in cell membranes, against damage from oxygen-free radicals. Foods rich in vitamin $\mathrm{E}$ are those from plant origin like seed oils, vegetables and whole grains. Most animal products are poor sources of this vitamin (14). However, feeding practices have changed in the past years and vitamin $\mathrm{E}$ supplementation of animal diets has garnered interest. Many studies (2, 3, 10) show that supplemental dietary vitamin $E$ improves meat quality by reducing lipid oxidation and enhancing color stability. It is also well known that vitamin E deposits in certain animal tissues. Regarding human nutrition, limited information exists about the vitamin $E$ supply of products from supplemented animals.

The objective of the present study was to examine the $\alpha$-tocopherol content of lean meat available in Switzerland. We also studied the efficacy of the same dietary vitamin $\mathrm{E}$ supplementation to pigs and laying hens in order to increase the $\alpha$-tocopherol content of the respective animal products and their vitamin $\mathrm{E}$ supply for human nutrition.

\section{Materials and methods}

\section{Comparison of different meat cuts}

The following meat cuts were purchased from different supermarkets and butcher's shops in Zurich (Switzerland): pork (chop and shoulder), beef (prime rib and shoulder), chicken (breast and thigh) and veal (chop). Sample size of every meat cut was 25 pieces. The meat cuts were transported to our laboratory, where the longissimus dorsi muscle (1.d.m.) from beef prime rib and chop (pork and veal) was immediately separated. The other meat cuts were trimmed of visible fat, skin and connective tissue. The lean meat samples were cut into pieces. The samples were stored at $-20{ }^{\circ} \mathrm{C}$ until the analytical procedure was performed.

Trial with pigs

Twelve growing pigs (castrates) were divided into two groups of six. The animals were fed a basal diet based on barley $(35 \%)$, maize $(30 \%)$, soybean meal $(10 \%)$ and sunflower meal $(10 \%)$. The remaining ingredients were potato protein, animal fat, lysine, minerals and vitamins. The diet of the control group was not enriched with $\alpha$-tocopherol and the diet of the vitamin $\mathrm{E}$ group was supplemented with $200 \mathrm{mg} \alpha$-tocopherol acetate $/ \mathrm{kg}$ feed. The analyzed $\alpha$-tocopherol concentrations in the diets were $15 \mathrm{mg} / \mathrm{kg}$ and $258 \mathrm{mg} / \mathrm{kg}$ feed for the control and vitamin $\mathrm{E}$ group, respectively. Water and feed were given ad libitum. The pigs were fattened from $25 \mathrm{~kg}$ to $105 \mathrm{~kg}$ body weight. The animals were slaughtered in a local abattoir. The liver was immediately removed and cooled. At 24 h postmortem, chops (1.d.m.) and adipose tissue samples were obtained.

\section{Trial with laying hens}

Ten laying hens were divided into two groups of five and fed either a basal diet or the basal diet supplemented with $200 \mathrm{mg} \alpha$-tocopherol acetate $/ \mathrm{kg}$ feed. The basal diet was composed of wheat $(30 \%)$, maize $(30 \%)$, soybean meal $(15 \%)$ and sunflower meal $(10 \%)$. The remaining ingredients were animal fat, lysine, methionine, minerals and vitamins. The analyzed $\alpha$-tocopherol concentrations in the diets were $15 \mathrm{mg} / \mathrm{kg}$ feed for the control and 213 $\mathrm{mg} / \mathrm{kg}$ feed for the vitamin $\mathrm{E}$ group. Water and feed were given ad libitum. After the diets were fed for 4 weeks, one egg of every hen was collected and stored at $4{ }^{\circ} \mathrm{C}$ until analysis.

\section{Chemical analysis, calculation and statistical methods}

The $\alpha$-tocopherol content was determined by the method of Rettenmaier and Schüep (17). For calculating the vitamin E:energy ratio (mg/MJ) of the different samples, the median and the energy values of Souci et al. $(18,19)$ were used. The vitamin $\mathrm{E}$ allowances recommended (women: $1.4 \mathrm{mg} / \mathrm{MJ}$, men: $1.2 \mathrm{mg} / \mathrm{MJ}$ ) do not consider preparation losses, whereas the recommendation for daily vitamin $E$ intake $(13 \mathrm{mg} /$ day $)$ takes into account preparation losses of $10 \%(8)$.

The statistical per capita meat consumption (slaughter weight) in Switzerland was the basis for calculating the average lean meat consumption. A percentage of lean meat of the slaughter weight of $55 \%, 65 \%, 66 \%$ and $50 \%$ for pork, beef, veal and poultry, respectively was considered. About $85 \%$ of the poultry meat consumed was chicken (20).

To calculate significant differences $(p<0.05)$ in $\alpha$ tocopherol content of different meat cuts, the analysis of variance (ANOVA) was computed by using Statgraphics 5.0. Significance of means was determined using Bonferroni's Multiple Range Test. The Mann-Whitney U-test was employed to determine differences in the $\alpha$-tocopherol content of animal products between the control and the vitamin E groups.

\section{Results and discussion}

In Table 1 the $\alpha$-tocopherol content and $\alpha$-tocopherol:energy ratio (mg/MJ) of different meat cuts available in Switzerland, are shown. Chicken thigh was the meat cut with the highest $\alpha$-tocopherol content, followed by chicken breast and pork shoulder muscles $(p<0.05)$. Our 
Table $1 \alpha$-Tocopherol content and $\alpha$-tocopherol:energy ratio ( $\mathrm{mg} / \mathrm{MJ}$ ) of different meat cuts and $\alpha$-tocopherol intake provided by the average daily meat consumption in Switzerland (1995)

\begin{tabular}{|c|c|c|c|c|c|c|}
\hline \multirow[t]{3}{*}{ Meat cuts } & \multicolumn{4}{|c|}{$\alpha$-Tocopherol } & \multirow{2}{*}{$\begin{array}{l}\text { Meat con- } \\
\text { sumption }\end{array}$} & \multirow{2}{*}{$\begin{array}{c}\alpha \text {-Tocopherol } \\
\text { intake }\end{array}$} \\
\hline & Mean \pm SD & Median & Content ${ }^{d}$ & Ratio & & \\
\hline & & $\mathrm{mg} / 100 \mathrm{~g}$ & & $\mathrm{mg} / \mathrm{MJ}$ & g/day & $\mathrm{mg} / \mathrm{day}$ \\
\hline Pork & & & 0.35 & & 53 & 0.19 \\
\hline Ld.m. & $0.27 \pm 0.10^{\mathrm{a}}$ & 0.26 & & 0.6 & & \\
\hline Shoulder & $0.52 \pm 0.23^{b}$ & 0.44 & & 1.0 & & \\
\hline Beef & & & 0.22 & & 30 & 0.07 \\
\hline L.d.m. & $0.26 \pm 0.16^{a}$ & 0.21 & & 0.5 & & \\
\hline Shoulder & $0.26 \pm 0.16^{2}$ & 0.22 & & 0.5 & & \\
\hline Veal (L.d.m.) & $0.29 \pm 0.11^{12}$ & 0.30 & 0.30 & 0.8 & 9 & 0.03 \\
\hline Chicken & & & 0.89 & & 13 & 0.12 \\
\hline Breast & $0.62 \pm 0.22^{\mathrm{b}}$ & 0.64 & & 1.4 & & \\
\hline Thigh & $1.20 \pm 0.53^{\mathrm{c}}$ & 1.14 & & 2.5 & & \\
\hline Sum & & & & & 105 & 0.41 \\
\hline German ${ }^{f}$ & & & Men: & 1.2 & Men: & $13(3 \%)$ \\
\hline Recommenda & tions (8) & & Women & 1.4 & Women: & $13(3 \%)$ \\
\hline
\end{tabular}

$\mathrm{n}=25 ; \mathrm{SD}$, Standard deviation; MJ, Megajoule; L.d.m., Longissimus dorsi muscle.

$a, b, c_{\alpha}$-Tocopherol contents (means) with unlike letters were significantly different $(p<0.05)$.

JFor calculating the average $\alpha$-tocopherol content of each animal species (pork, beef and chicken), the mean of the two median values was used.

For calculating the $\alpha$-tocopherol:energy ratio (mg/MJ) the median value and the energy value in Souci et al. $(18,19)$ were considered. In parentheses the covering of the recommendations expressed as percentage is shown.

findings for the vitamin $E$ content of chicken were higher than the values of McCance and Widdowson (13), Souci et al. (18) and Elmadfa et al. (5). One explanation for this might be that the diets of broilers in Switzerland are now very often supplemented with vitamin $E$ (Pfirter, 1996, personal communication). This may account for the relative high $\alpha$-tocopherol content found in chicken meat, especially in chicken thigh. The lowest vitamin E concentrations were found in pork (1.d.m.), beef (1.d.m. and shoulder muscles) and veal (1.d.m.) and no statistical significant difference was found in the $\alpha$-tocopherol content of these meat cuts. McCance and Widdowson (13) published lower vitamin $E$ concentrations for lean pork and beef $(0 \mathrm{mg}$ and $0.15 \mathrm{mg} / 100 \mathrm{~g}$, respectively). In relation to our values, data from Souci et al. (19) and Elmadfa et al. (5) showed comparable vitamin $\mathrm{E}$ concentrations in pork $(0.37$ and $0.30 \mathrm{mg} / 100 \mathrm{~g})$ and higher contents of beef $(0.48$ and $0.5 \mathrm{mg} / 100 \mathrm{~g})$. Also, the published vitamin $\mathrm{E}$ content of veal chop by Elmadfa et al. (5) was higher $(0.6 \mathrm{mg} / 100 \mathrm{~g}$ chop) than our value. Similarly, an explanation for the variability in the reported vitamin $\mathrm{E}$ contents might be different vitamin $\mathrm{E}$ contents of animal diets (4).

Lean meat was not an important vitamin $\mathrm{E}$ supplier in the nutrition of the Swiss. The vitamin $\mathrm{E}$ intake provided with the average daily lean meat consumption in Switzerland was $0.41 \mathrm{mg}$ (Table 1). This vitamin $\mathrm{E}$ intake covered $3 \%$ of the recommendation for the daily vitamin E intake given by the German Nutrition Society (8). Only
Table $2 \alpha$-Tocopherol content and $\alpha$-tocopherol:energy ratio $(\mathrm{mg} / \mathrm{MJ})$ of different products from animals fed a control or a vitamin E supplemented diet

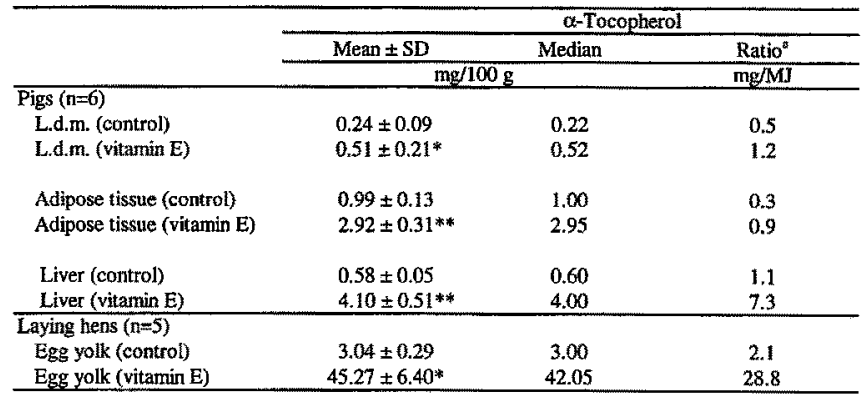

*, $\mathrm{p}<0.05 ; * *, \mathrm{p}<0.01$.

SD, Standard deviation; MJ, Megajoule; L.d.m., Longissimus dorsi muscle.

aFor calculating the $\alpha$-tocopherol:energy ratio (mg/MJ) the median value and the energy values in Souci et al. (19) were considered. Recommended allowances for vitamin $\mathrm{E}$ are: $1.2 \mathrm{mg} / \mathrm{MJ}$ for men and $1.4 \mathrm{mg} / \mathrm{MJ}$ for women (8).

chicken thigh with its relatively high vitamin E:energy ratio $(2.5 \mathrm{mg} / \mathrm{MJ})$ was a good vitamin $\mathrm{E}$ supplier for human nutrition.

In Table 2, the $\alpha$-tocopherol contents of longissimus dorsi muscle, adipose tissue and liver of the control and vitamin $E$ groups are shown. Dietary vitamin E supplementation to pigs resulted in a significant increase of the $\alpha$-tocopherol content of 1.d.m. $(p<0.05)$, adipose tissue and liver $(p<0.01)$. Also, the study with laying hens showed that a vitamin $E$ supplementation significantly increased the $\alpha$-tocopherol content of eggs (yolk), compared to the control group ( $\mathrm{p}<0.05$ ). Although, in both trials (pigs and laying hens) the diets were supplemented with $200 \mathrm{mg} \alpha$-tocopherol acetate $/ \mathrm{kg}$ feed, the $\alpha$-tocopherol accumulation differed among the examined animal products according to the following ranking: egg yolk $>$ liver $>$ adipose tissue $>$ longissimus dorsi muscle. Compared to the control groups, the $\alpha$-tocopherol content of egg yolk, liver, adipose tissue and pork 1.d.m. of the vitamin $\mathrm{E}$ groups were 15 -fold, sevenfold, threefold and twice as high, respectively. Meat (1.d.m.) and adipose tissue of the vitamin $E$ group were poor vitamin $E$ suppliers. The vitamin E:energy ratios for these samples were 1.2 and $0.9 \mathrm{mg} / \mathrm{MJ}$, respectively. The increase of the $\alpha$-tocopherol content of liver by the vitamin $\mathrm{E}$ supplementation was important for human nutrition. Considering an energy value of $549 \mathrm{~kJ} / 100 \mathrm{~g}$ (19) the vitamin E:energy ratio of the liver samples of the vitamin $\mathrm{E}$ group increased to $7.3 \mathrm{mg} / \mathrm{MJ}$. However, pig liver is consumed only in very low quantities and a high consumption is not favorable for different reasons. Remarkable is the observation that the 1.d.m. $\alpha$-tocopherol content of the control group was comparable to those of pork chop samples (l.d.m.) at the retail level. Therefore, it can be 
concluded that the diets of pigs in Switzerland were not supplemented with significant quantities of vitamin $\mathrm{E}$.

Many studies have investigated the effect of a vitamin E supplementation of animal diets on the meat $\alpha$-tocopherol content. Vogg (22), Asghar et al. (3) and Monahan et al. (15) fed pigs different levels of vitamin $E$. The highest 1.d.m. $\alpha$-tocopherol value $(0.80 \mathrm{mg} / 100 \mathrm{~g})$ was reported by Monahan et al. (15). In their study pigs received a dietary vitamin $E$ supplementation of $200 \mathrm{mg}$ $\alpha$-tocopherol acetate $\mathrm{kg}$ feed. Arnold et al. (1), Arnold et al. (2) and Liu et al. (12) fed steers $\alpha$-tocopherol acetate enriched diets. Arnold et al. (2) reported that the group of steers receiving $2000 \mathrm{mg}$ vitamin E/day had a $\alpha$-tocopherol content of $0.82 \mathrm{mg} / 100 \mathrm{~g}$ in gluteus medius muscle and $0.67 \mathrm{mg} / 100 \mathrm{~g}$ in longissimus lumborum muscle. Engeseth et al. (6) showed that $500 \mathrm{mg}$ vitamin E/day given to veal calves for 12 weeks after birth resulted in increased $\alpha$-tocopherol concentration in 1.d.m. (0.61 $\mathrm{mg} / 100 \mathrm{~g}$ ). These studies show that meat from supplemented animals is not a good vitamin E source. Liu et al. (12) calculated that even an exclusive beef consumption in the USA ( $84 \mathrm{~g} /$ day) from supplemented animals would only provide $0.56 \mathrm{mg}$ vitamin E/day. However, chicken meat, especially chicken thigh, is possibly an exception. Lin et al. (11) and King et al. (10) used 100 $\mathrm{mg}$ and $150 \mathrm{mg}$ of vitamin $\mathrm{E} / \mathrm{kg}$ broiler feed, respectively. The resulting $\alpha$-tocopherol contents of chicken thigh were $1.0 \mathrm{mg} / 100 \mathrm{~g}$ and $1.3 \mathrm{mg} / 100 \mathrm{~g}$, respectively. Nepp et al. (16) tested the compatibility of a high vitamin $E$ supplementation in broilers. They enriched diets of broilers with $0,100,1000,10000,20000 \mathrm{mg} \alpha$-tocopherol acetate $/ \mathrm{kg}$ feed. The resulting $\alpha$-tocopherol contents of chicken thigh were $0.11,0.49,3.18,9.05$ and 12.16 $\mathrm{mg} / 100 \mathrm{~g}$, respectively. It should be noted that these high vitamin $\mathrm{E}$ supplementations (> $100 \mathrm{mg} / \mathrm{kg}$ feed) are economically not useful.

By dietary vitamin $E$ supplementation of laying hen diets, egg yolk became a good vitamin $\mathrm{E}$ source (28.8 $\mathrm{mg}$ vitamin $\mathrm{E} / \mathrm{MJ}$ ). This is in agreement with many other studies. Garwin et al. (7) and Jiang et al. (9) supplemented the feed with $200 \mathrm{mg}$ vitamin $\mathrm{E} / \mathrm{kg}$. The $\alpha$-toco- pherol concentrations in egg yolk were $18.8 \mathrm{mg} / 100 \mathrm{~g}$ and $24.6 \mathrm{mg} / 100 \mathrm{~g}$ egg yolk, respectively. Although, in our study the laying hens also received $200 \mathrm{mg} \alpha$-tocopherol acetate $/ \mathrm{kg}$ feed, the $\alpha$-tocopherol concentration in egg yolk $(45.3 \mathrm{mg} / 100 \mathrm{~g})$ was much higher compared to the study of Garwin et al. (7) and Jiang et al. (9). One reason might be that we collected the eggs after a feeding period of 28 days, whereas Jiang et al. (9) collected the eggs after 21 days. Surai and Ionov (21) showed in their study that supplementing laying hens with vitamin $\mathrm{E}$, caused an increase of the egg yolk $\alpha$-tocopherol concentration to a maximum level and than the $\alpha$-tocopherol content decreased again and stabilized at a lower level. They supplemented laying hens with $10,100,1000$ and $10000 \mathrm{mg}$ vitamin $\mathrm{E} / \mathrm{kg}$ feed for 60 days. The maximum egg yolk $\alpha$-tocopherol content of the group receiving $10000 \mathrm{mg} / \mathrm{kg}$ was found after 3 weeks $(1025 \mathrm{mg} / 100 \mathrm{~g})$. Then the $\alpha$-tocopherol concentration decreased again and stabilized at a level of $370 \mathrm{mg} / 100 \mathrm{~g}$. The maximum egg yolk $\alpha$-tocopherol levels of the groups receiving 100 $\mathrm{mg} / \mathrm{kg}$ and $1000 \mathrm{mg} / \mathrm{kg}(54.0 \mathrm{mg} / 100 \mathrm{~g}$ and $363 \mathrm{mg} /$ $100 \mathrm{~g}$ ) were detected later and were lower compared to the group with the highest vitamin $\mathrm{E}$ level. Therefore, in further studies it should be examined after how many days of feeding supplemental vitamin $\mathrm{E}$ the $\alpha$-tocopherol concentration in egg yolk remains stable.

In conclusion, lean meat is generally not an important vitamin $\mathrm{E}$ supplier in human nutrition, not even from supplemented animals. One exception might be chicken meat, especially chicken thigh. However, the average daily chicken meat consumption is low and therefore, it is also not an important vitamin $\mathrm{E}$ source. A dietary vitamin $E$ supplementation to laying hens resulted in an increase of vitamin $E$ concentration in egg yolk, so that egg yolks from these laying hens were potent vitamin $\mathrm{E}$ suppliers for human nutrition.

Acknowledgements We would like to thank M. Memmen and C. Senaux for their technical assistance. We also thank Prof. M. Kreuzer for help in preparing the manuscript.

\section{References}

1. Arnold RN, Scheller KK, Arp SC, Williams SN, Buege DR, Schaefer DM (1992) Effect of long-or short-term feeding of $\alpha$-tocopherol acetate to holstein and crossbred beef steers on performance, carcass characteristics and beef color stability. J Anim Sci 70:3055-3065

2. Amold RN, Arp SC, Scheller KK, Williams SN, Schaefer DM (1993) Tissue equilibration and subcellular distribution of vitamin $E$ relative to myoglobin and lipid oxidation in displayed beef. $J$ Anim Sci $71: 105-118$
3. Asghar A, Gray JI, Booren AM, Gomaa EA, Abouzied MM, Miller ER, Buckley DJ (1991) Effects of supranutritional dietary vitamin $\mathrm{E}$ levels on subcellular deposition of $-\alpha$-tocopherol in the muscle and on pork quality. J Sci Food Agric 57;31-41

4. Bässler $\mathrm{KH}_{3}$ Grühn $\mathrm{E}$, Loew $\mathrm{D}$, Pietrzik K (1992) Vitamin-Lexikon. Gustav Fischer Verlag, Stuttgart, pp 254-280

5. Elmadfa I, Aign W, Muskat E, Fritzsche D, Cremer HD (1996) Die große Vitamin- und Mineralstoff-
Tabelle. Gräfe und Unzer GmbH, München

6. Engeseth NJ, Gray JI, Booren AM, Asghar A (1993) Improved oxidative stability of veal lipids and cholesterol through dietary vitamin $\mathrm{E}$ supplementation. Meat Sci 35:1-15

7. Garwin JL, Morgan JM, Stowell RL, Richardson MP, Walker MC, Capuzzi DM (1992) Modified eggs are compatible with a diet that reduces serum cholesterol concentrations in humans. $\mathbf{J}$ Nutr 122:2153-2160 
8. German Nutrition Society/Deutsche Gesellschaft für Ernährung (1995) Empfehlungen für die Nährstoffzufuhr. Umschau-Verlag, Frankfurt

9. Jiang YH, McGeachin RB, Bailey CA (1994) $\alpha$-Tocopherol, $\beta$-carotene, and retinol enrichment of chicken eggs. Poultry Sci 73:1137-1143

10. King $A J$, Uijttenboogaart $T G$, Vries de AW (1995) $\alpha$-Tocopherol, $\beta$-carotene and ascorbic acid as antioxidants in stored poultry muscle. $\mathrm{J}$ Food Sci 60:1009-1012

11. Lin CF, Gray J, Asghar A, Buckley DJ, Booren AM, Flegal CJ (1989) Effects of dietary oils and $\alpha$-tocopherol supplementation on lipid composition and stability of broiler meat. J Food Sci 54:1457-60, 1484

12. Liu Q, Scheller KK, Schaeffer DM, Arp SC, Williams SN (1994) Dietary $\alpha$-tocopherol acetate contributes to lipid stability in cooked beef. $J$ Food Sci 59:288-290
13. McCance RA, Widdowson EM (1991) The Composition of Food 5th ed. Royal Society of Chemistry, Letchworth

14. Meydani M. (1995) Vitamin E. Lancet $345: 170-175$

15. Monahan FJ, Bückley DJ, Morrissey PA, Lynch PB, Gray JI (1992) Influence of dietary fat and $\alpha$-tocopherol supplementation on lipid oxidation in pork. Meat Sci 31:229-241

16. Nepp A, Schaarmann G, Schulze E, Richter G, Flachowsky G (1996) Untersuchung der Verträglichkeit hoher Vitamin-E-Gaben bei Mastküken. Proc Soc Nutr Physiol 5:138

17. Rettenmaier R, Schüep W (1992). Determination of vitamin $A$ and $E$ in liver tissue. Internat $J$ Vit Nutr Res 62:312-317

18. Souci SW, Fachmann W, Kraut H (1989) Food composition and nutrition tables. 4th ed. Wissenschaftliche Verlagsgesellschaft. Stuttgart
19. Souci SW, Fachmann W, Kraut H (1994) Food composition and nutrition tables. 5th ed. Medpharm Scientific Publishers, Stuttgart

20. Swiss Meat Board/Schweizerische Genossenschaft für Schlachtvieh und Fleischversorgung (1995) Market report, Bern, Switzerland

21. Surai PF, Ionov IA (1992) Some biochemical aspects of hyper-vitaminosis $\mathrm{E}$ in hens. Proceedings 19th World's poultry congress, Amsterdam 19-24 September. Volume 1. pp 578-581

22. Vogg DM (1989) Über die Verteilung von Polyenfettsäuren und $\alpha$-Tocopherol in den Geweben des Schlachtkörpers von Mastschweinen, Ph.D. thesis no. 8876. Swiss Federal Institute of Technology Zurich 